\title{
Licitação do "GÁS DE XISTO": Carta aberta à Excelentíssima Senhora Presidenta Dilma Rousseff
}

\author{
Senhora Presidenta,
}

A Agência Nacional do Petróleo - ANP - anunciou a decisão de incluir o chamado gás de xisto na próxima licitação, em outubro, de campos de gás natural em bacias sedimentares brasileiras.

Com todo o respeito e admiração, vimos recorrer a Vossa Excelência no sentido de excluir do edital esse tipo especial de jazida, dando um prazo de governo, da ordem de cinco anos, após o qual seja tomada uma decisão estratégica sobre a conveniência de explorar gás de xisto no Brasil. Os motivos e justificativas para isto podem ser assim resumidos:

O anúncio da ANP da intenção de explorar gás de xisto é intempestivo e não foi antecedido de qualquer consulta pública, discussão ou diálogo com a comunidade técnica e científica do País. Está na contramão da transparência administrativa e dos princípios democráticos do próprio Governo.

1. No Brasil, a produção de gás natural é um componente importante e crescente da matriz energética, graças às descobertas de novos campos. O Plano Decenal de Expansão de Energia - PDE 2012-2021, lançado em janeiro, procura tirar partido da abundância de petróleo e gás natural. Ele prevê que haverá "ampliação da produção de petróleo de 2,1 para 5,4 milhões de barris/dia e da produção de gás natural, de 65,9 milhões para 190 milhões de $\mathrm{m}^{3} / \mathrm{dia}$.

Em 2021, segundo o Plano, o consumo total de gás natural será da ordem de 65,9 milhões de m³/dia,ou seja, apenas $1 / 3$ da produção daquele ano.

Neste cenário positivo, parece não haver justificativa econômica ou de demanda para incluir uma fonte específica de gás - o chamado gás de xisto. Aliás, ele não é sequer citado no Plano 2012-2021. Por que a pressa de colocar na pauta de licitação a explotação desse tipo de jazida?

2. A explotação de gás de xisto, apesar do sucesso tecnológico e econômico apresentado principalmente nos Estados Unidos, tem sido muito questionada pelos riscos e danos ambientais envolvidos. Enquanto o gás natural e o petróleo ocorrem em estruturas geológicas e nichos próprios, o gás de xisto impregna toda a rocha ou formação geológica. Nesta condição, a tecnologia de extração de gás está embasada em processos invasivos da camada geológica portadora do gás, por meio da técnica de fratura hidráulica, com a injeção de água e substâncias químicas, podendo ocasionar vazamentos e contaminação de aquíferos de água doce que ocorrem acima do xisto. Esta é uma grande preocupação dos técnicos e gestores da área de recursos hídricos e meio ambiente.

3. É sabido que os métodos convencionais de perfuração de poços e extração de petróleo ou gás podem acarretar acidentes ambientais e danos aos aquíferos. No caso do gás de xisto, esse risco potencial é ainda maior por causa da técnica utilizada. É o caso das bacias sedimentares brasileiras. É, por exemplo, a situação do Aquífero Guarani, na Bacia do Paraná, a principal reserva de água subterrânea do Cone Sul, que seria atravessado pelas perfurações e processos de injeção na camada inferior, de xisto.

Aqui, é bom lembrar que o Plano Decenal adota as seguintes premissas:"opção por projetos que evitem áreas sensíveis do ponto de vista socioambiental; preferência por projetos que apresentem menores impactos e maiores benefícios sociais, ambientais e econômicos“. Não parece ser o caso do gás de xisto.

Senhora Presidenta, permita-nos retornar ao apelo inicial. Até por uma questão de prudência, parece-nos de todo conveniente adiar por um prazo de cinco anos qualquer decisão sobre a explotação de gás de xisto. Seria o tempo de avaliar a tecnologia utilizada, ouvir a comunidade técnica e científica e acompanhar o processo nos países que a utilizam. É o tempo de amadurecer uma estratégia para a próxima década.

Queira aceitar nossos protestos de estima e admiração,

Gerôncio Albuquerque Rocha

Geólogo, funcionário do Depto. Águas e Energia Elétrica de São Paulo (aposentado), São Paulo, SP.

Ricardo César Aoki Hirata

Geólogo, Professor da Univ. São Paulo e Diretor do CEPAS, Centro de Estudos e Pesquisas em Águas Subterrâneas, São Paulo, SP.

Luiz Fernando Scheibe

Geólogo, Professor Emérito da Univ. Fed. Santa Catarina e Coordenador do Projeto REDE GUARANI/SERRA GERAL em SC, Florianópolis, SC 